\title{
The Expressive Turn of Citizenship in Digital Late Modernity
}

\author{
Jakob Svensson \\ Department of Media and Communication Studies, Karlstad University, Box 882, SE- 65188 Karlstad \\ jakob.svensson@kau.se, +4654 7001893
}

\begin{abstract}
The purpose of this paper is to connect the idea of expressive rationality to current debates on citizenship and political participation online. Socialising, cultural consumption/ production, identity management, information and publication strategies are both different and accentuated in digital, networked and late modern environments. In the paper I argue that the kind of network sociability that is emerging today favours an expressive form of rationality. I also claim that expressive rationality transcends the bipolar instrumental - communicative dimension that has been so important for normative theorizing in Political (and Social) Sciences and hence is a more rewarding theoretical concept for understanding political participation in digital late modernity.
\end{abstract}

Keywords: Expressive Rationality, Late Modernity, Digital Communication, Networked Individualism, Communicative Rationality, Instrumental Rationality

Acknowledgement: This article has been made possible with support from the Wahlgrenska Foundation.

r oday, almost everyone agrees that the rise of digital communication and Internet has been remarkable. Many scholars connect these transformations of communication patterns to us entering into a new kind of society (Benkler, 2006 \& Shirky, 2009). With the possibility of communicating many-to-many in digital networks, it is argued that we are leaving mass society behind.

Concerning political participation and citizenship the Internet is considered the new arena for the political in connected societies, lowering the political threshold with new and different forms for engaging people in deliberations about the structure and organisation of our society. When more and more people socialise, organise, contribute, inform and publish their concerns and themselves on the Internet, political participation takes on different meanings and citizenships are enacted differently.

The purpose of this paper is to connect previous ideas of expressive rationality (see Svensson, 2008a) to current debates on citizenship and political participation online. I will argue that the kind of network culture that is emerging in contemporary digital late modernity underlines this expressive form of rationality that transcend the bipolar instrumental - communicative dimension that has been so important for normative theorising in Political (and Social) Sciences. Socialising, cultural consumption/production, identity management, information and publication strategies are both different and accentuated in digital, networked, convergent and late modern environments.

\section{Political Participation and Digitalisation in Late Modernity}

Sociologists often refer our time as late modern (Giddens, 1991; Bauman, 2001). Dahlgren (2006) characterises late modernity by identifying two interrelated cultural processes at work: 
dispersion of unifying cultural frameworks and individualisation. The first refers to the increasing pluralisation, fragmentation and nichification of society along lines of media consumption, cultural interests, lifestyles, interests, tastes et cetera (ibid.). Individualisation refers to lacking a sense of social belonging and a growing sense of personal autonomy (ibid.). In other words, the collective and traditional has faded in importance in favor of the never-ending individual identity formation project (Giddens, 1991). When individual identity can increasingly be crafted and managed, the making of oneself becomes more important with self-realisation as an end in itself to strive for (Giddens, 1991; Beck, 1998). However self-realisation is elusive since it can hardly be achieved once and for all. The making and moulding of the self is a continuous process where not least capitalist consumption society will make sure there is always something new to strive for and more things with which to connect your self-identity. This underlines reflexivity as a consistent theme in late modernity (which is sometimes referred to as reflexive modernity, see Giddens, 1991; Beck, 1995). Reflexivity implies that we consider ourselves and our practices from different perspectives, re-considering previously acquired knowledge and not taking anything for granted. According to Beck (1998) this will lead to increased doubts, questionings, and in the end a risk society. In particular, since it is our life choices and individual identity, constantly being scrutinised, redefined and being subjects for our reflections. In this way reflexivity extends all the way into the core of the self and is linked with individualisation in late modernity (Giddens, 1991). As I shall attend to next, due to these developments it has become more difficult today to find forms for political participation within traditional representative parliamentary institutions.

At the same as western societies enters into late modernity, we experience changing practices of citizenship. Representative democracy combined with market capitalism was dominating western political philosophy to the extent that Fukuyama (1992) declared the end of history, with liberal representative democracy as the ultimate stage in the development of human government. But liberal representative democracy faces challenges today that hardly could be predicted at its dawning in a modern era where identities were more solid and confined to the different strata of industrialised society. The supposed victory of liberal democracy seems to have accompanied social disintegration and voter alienation (Carter \& Stokes, 1998). Some claim that inhabitants are withdrawing away from collective endeavours and a supposedly vivid agora full of debating citizens, and are becoming increasingly sceptical and distrusting, with the result of a decrease in political participation (see Bauman, 2001; Muhlberger, 2006). These dystopian accounts are easily justified with reference to parliamentary politics, which in the west experiences low participation in elections and decreasing membership in political parties. For example, the EU elections of June 2009 were claimed to be the biggest trans-national elections in history. However, only $43,4 \%$ of the electorate chose to cast their vote, making participation the lowest in the 30 years of EU election history. Low participation in elections together with decreasing faith in politicians and membership in political parties has launched a debate on civic apathy and distrust followed by proclamations of a current legitimacy crisis of parliamentary politics and its representatives (Petersson \& Westholm \& Blomberg, 1989). It is true that citizens in western societies more frequently declare themselves to be dissatisfied (Bentivegna, 2006). We are thus witnessing a civic withdrawal away from formal politics, away from larger collective identities and community sensibilities. Carl Boggs refers to this as the great retreat (2000).

Some claim that late modern individualism is to be blamed for citizens' withdrawal away from traditional representative democratic sites. Bauman (2001), who is highly critical of late modern individualism, equates the civic withdrawal away from formal politics, with a larger withdrawal away also from collective identities and community sensibilities. But despite decreasing participation in parliamentary arenas, there are other sites of politics, not solely limiting political participation to representative democracy, suggesting new loci for citizenship practices. A more positive account of late modern political participation is provided by Beck $(1995,1998)$ by his concept of sub-politics. $\mathrm{He}$ regards individualisation and dispersion of unified cultural frameworks as not necessarily inhibiting political participation and citizenship. Supporting this more positive account is the recognition of new arenas for political participation, such as everyday life at home, on the street or 
online, arenas with activities such as signing petitions, voicing concerns and protests by creating and joining new groups and associations outside the Parliament (Petersson \& Westholm \& Blomberg, 1989; Beck, 1995; Dahlgren, 2001). These arenas seem to be more short-lived and single-issue oriented. But they underline that late modern processes of individualisation have resulted in, not a general withdrawal from political participation per se, but rather a more lifestylebased approach to politics (Giddens, 1991). It seems that political participation has increasingly become part of an individual self-realisation project. As an example of this new form of engagement, when studying civic communication in the south Swedish municipality of Helsingborg (see Svensson, 2008b), I witnessed the mobilisation of a quite significant number of young music lovers in order to save a popular rock club that local politicians wanted to turn into a conference centre. Through Internet and mobile technology, they gathered signatures, protested against the municipal plans, got older inhabitants and residents interested in architecture of the old railway station in which the club was housed, to protest together with them. This illustrates the type of lateral electronic-based engagement that is emerging today, engagement that is based in late modern life-practices, outside parliamentary politics, and engagement that is mobilised around one particular issue, attracting new forms of temporary collectives. It should be underlined that this shift towards life-style politics is a slow process of changing attitudes rather than a distinct rupture (hence I use the term late modernity instead of post modernity). But nonetheless we are witnessing a change in civic political practices today and this is considered a serious problem for liberal representative democracy and parliamentary institutions. The struggle to get more citizens reengaged in traditional politics has thus begun.

As the protestors in Helsingborg exemplify, it is in this context the Internet enters into the discussion, both as a signature tool for life politics, as well as a remedy for current disinterest in parliamentary politics, portraying the citizenry as engaged and interactive with the aid of web 2.0 technologies and emerging social networking platforms. Indeed, there has emerged a whole range of research from a techno-optimist perspective, where technology is viewed as a potential saviour of all kinds of problems democracy is facing (Coleman \& Blumler, 2009). Whether the Internet and digitalisation will break with established societal power structures might be argued against (see the chapters in Loader, 2007; and Olsson \& Dahlgren, 2010 anthologies). On the other hand we have techno-pessimists that claim that digital democracy is just a myth (Hindman, 2009). Technology is neither good, nor bad in itself, but is not neutral either. The internet is changing the practice of political participation and meanings of engagement (see Dahlgren, 2009). The point I want to make here is that societal and cultural changes in late modernity are happening at the same time as we experience a technological shift towards digitalisation. When digital information technologies become increasingly important for communicating in connected communities, society takes on new and different meanings. Hence it is in the dialectics and intersections of technology, culture and society that we should depart when trying to understand contemporary political participation and citizenship.

Here I find Castells' (2001) notion of networked individualism as the dominant form of sociability of our time particularly interesting. Networked individualism suggests that we today have greater power in shaping the networks with which we communicate and inform ourselves (ibid.). But this does not mean that it is all in the hands of the user. Networked individualism also underlines the network as important for understanding individual evolution and fosterage where individuality is rendered useless without network visibility and references to other nodes and their supposed connotations (Castells, 2001; Donath \& Boyd, 2004; Walther \& Van Der Heide \& Kim \& Westerman \& Tong, 2008). Thus, in late modernity, it is through a reflexive processes of identification and in emerging networks of communication that we tie our selves to others, to causes, to activities and it is in communicative networks online that we socialise to an increasing extent. As an example, in November 2010 the time spent with friends online surpassed the time spend with friends offline among Swedish youth according to the Swedish Media Council (Medierådet, 2010). Therefore, I believe we are not capturing the whole picture when referring to our time as only late modern. Rather I would describe western and connected societies as entering into a digital late modernity. 
In summary, the sociological understanding of our time as late modern, underlines a cultural perspective with its focus on changing patterns of sociability, the mental and discursive space where the individual and society meet and relate to each other. Individualism and reflexive processes of identification are central aspects in contemporary socio-technological dialectics, most commonly addressed from the concept of networks, constituting the metaphor describing interaction patterns and sociability in digitalised cultures (see Castells, 2001; Terranova, 2004; Benkler, 2006). The network structure underlines a reflexive rationale of linking the self to different collectives. Through digital networks we negotiate ourselves, and technology itself is part of this negotiation (Ekelin, 2007; Roberts, 2009). This is a mutual dialectical construction where neither technology nor society or the individual causes the other. Since representative democracy has its roots in an era marked by modernisation and industrialisation, contemporary withdrawal from its institutions may be understood as a consequence of new forms of sociability and an increasing emphasis on processes of identification in digital late modernity (see Coleman \& Blumler, 2009). Instead of joining a political party and vote, we experience new forms of expressing political engagement and new ways of participating that rather underline the late modern preoccupation with identity negotiation and maintenance.

\section{Citizenship Practices and the Political}

So how are we to conceive of citizenship and the political in these new environments? Citizenship has been used in many different circumstances, connoting different things to different audiences in different circumstances (for a good overview see Kivisto \& Faist, 2007). The concept is usually understood as consisting of three components: membership, participation, rights and duties; components that stands and fall together (Bellamy, 2008). Membership is tied to a political community. Rights and duties are attached to this membership together with the possibility of free and equal participation in the community's political processes (Bellamy, 2008). In order to keep its normative force and relevance as an analytical tool, I have argued that it is important to make a distinction between human beings in general and citizens in particular (Svensson, 2008b). The recognition of some centre of power is important in order to address right claims and to accept duties and regulations put on you as a citizen. Hence citizenship is best understood as a relation to some kind of authority.

Some argue that citizenship could refer to any group, not only political ones or the nation state (Smith, 2002; Bosniak, 2006). But the sphere where citizenship is enacted is commonly understood as political (Bosniak, 2006), or at least it becomes political when certain actions and identities are performed there (which is increasingly the case in late modernity which ideas of sub-, and lifepolitics underline, see Beck, 1995; Giddens, 1991). It then becomes crucial to delineate the political. Defining the political is also an important key to analysing the Internet and its democratic and citizenship potential. Techno-optimists tend to equate every link, every social forum as a sign of political participation whereas pessimists dismiss what others claim to be online political participation as mere narcissistic self-promotion. It is important to underline that interactivity is not automatically political; it has to be made political (Andrejevic, 2009). Thus it is crucial to know what we are talking about when we label some practices as political or and others as non-political.

The political has been conceived of as a social construction, continuously being defined by the practices labelled as political (Dahlgren, 2001). This broad and social constructionist definition of the political is appealing. However, for analytical purposes the political should at least be demarcated broadly to concerns of the organization and structure of society (Nord, 2008). Power is an important component of the concept, especially if linking political participation to an understanding of citizenship as a relation to some kind of authority. The practices of politics in these relations often depart from a principle of equality, the equal division of society's common goods (Rancière, discussed by Arsenjuk, 2005). Concerning this division, different groups and communities may have divergent opinions and thus enter into debate in some kind of public sphere. How to address issues of the organisation of society, formulate ideas of how to divide its 
common goods as equal as possible, together with my focus on the expressive rationale of citizenship practices (as I will attend to later), concerns discursive and relational aspects of power.

Political participation and citizenship is often discussed as a form of community membership practice. Today it is important to keep in mind that the political community does not have to come in the shape of the nation state. The notion of community is not only tied to territoriality, but also to interest. Defining community around boundaries of interest makes more sense in digital late modernity as sociability increasingly transcends state territory and instead unites users around cultural interests, lifestyles and tastes. In other words, community then rather refers to a group of people with a common ways of meaning-making. The relation to community does not have to be fixed. Communities in contemporary late modern societies are porous, casual and debated constellations and thus far from predetermined. Meaning-making as the defining character of community enables us to theorize about citizenship, making the concept useful even in cultures characterised by reflexivity, networks, physical and communication mobility and reach.

Combining the above definitions of the political and community, we end up with an understanding of political community as an ensemble of people concerned with the organisation of society and making sense of these concerns in a similar way. When people then participate and act upon shared meanings, address issues of the structure of society and the just division of its common goods, they enter into the practice of citizenship. Such addresses and practices do not have to be purposeful engagement, as civic republicans would argue (see Bosniak, 2006). In late modernity the political may occur outside of the Parliament and all over the sociocultural landscape. Citizenship practices do not have to originate from within a self-proclaimed political community, but they have to relate to an authority in some way or another. In this way we can distinguish between political participation from other kinds activities.

Applying the discussion of the fluidity of (political) communities, civic rights and duties cannot be conceived of as fixed or stable entities. The rights that define citizenship are undergoing a continual process of redefinition, not least through the political participation of citizens themselves. Accepting such structuring and dialectic relationship between the political community and participation, participation becomes entangled into the very core of the concept of citizenship. In this sense citizenship as membership with rights and benefits attached to it, cannot be sustained without members participating for the forth living of citizenship and its promise of equality, tolerance and democracy. Citizenship thus implies the capacity to participate and the duty to use this capacity on which our other rights and democracy depend (Bellamy, 2008). Citizenship is thus best understood as an activity, the act of doing something, rather than as a fixed status, membership merely ascribing certain people as citizens or non-citizens (see also Svensson 2008b). From a discursive framework, citizenship is best analysed as a process, conflating political participation with citizenship so it becomes almost the same thing. In a similar vein Turner (1994) uses a definition of citizenship as an ensemble of meaning-making practices that constitutes individuals as members in a community. The character of this community is influenced by peoples' participation, which in turn is influenced by the political authority in relation to which citizens participate.

Research on the Internet from a citizenship perspective has mostly focused on new possibilities to exercise rights and duties due to the mediums interactive technology and its potential to reach and activate a new and young crowd (Dahlberg, 2005). This evaluation of the Internet's democratic potential often takes it starting point from established and traditional perceptions of a representative democracy consisting of citizens as interested lay advisors to elected politicians and expert whitecollar state officials. As I shall attend to next, from a democratic perspective the Internet is most often studied as a locus that perhaps may approximate Habermasian ideas of ideal speech situations of equal, communicative and unrestrained communication. Or on the other hand, in studies of political communication the Internet is conceived of as an instrument for achieving strategically defined purposes (in elections for example, see Anduiza, 2009). However, these perspectives overlook that Internet and digital practices also are in dialectal relationship to sociocultural processes in digital late modernity. Networked individualism underlines the importance of identification, self-realisation and expression for assessing political participation, citizenship and 
democracy in contemporary societies. And in many cases political participation occurs from nonparliamentary, sub-political, activist or life-political settings since the political can emerge from all over the socio-cultural landscape in digital late modernity.

\section{The Instrumental-Communicative Rationality Dichotomy Revisited}

There has been a deliberative turn within academia. Today deliberative theories are influential within public administration (Svensson, 2008b), sometimes leading to online experiments under the promise of E-participation (Ekelin, 2007). This deliberative turn has renewed interest in the wellknown debate around instrumental and communicative rationality. I will argue against both these understandings here, putting forwards an expressive account rationality as more accurate for understanding and assessing citizenship practices and political participation, especially in reflexive and individualised digital late modernity with political participation increasingly taking place online.

Instrumental rationality refers to agents choosing from a range of different actions, and picking the one they believe most appropriate for achieving the ends they desire (Mueller, 1989). Hence, rationality becomes an instrument for reaching pre-defined goals. Through theories of New Public Management, instrumental understandings of rationality had a considerable influence in public administration in the 1990's (not least in Swedish municipalities, see Montin, 2002). The dominant discourse considered inhabitants as instrumental and motivated by their own self-interest, hence becoming citizens when consuming municipal welfare, claiming their right to welfare programs. At the same time as inhabitants adopted a more consumer-oriented view of democratic politics, politicians like-wised treated them as consumers by marketising the public sector (Bellamy, 2008). Instrumental discourses are still influential today when motivating a digitalisation of public administration. In her doctoral dissertation, Ekelin (2007) defines E-government as aiming at rationalising and modernising municipalities, enabling a better and more efficient public administration to be realised. Here, Internet and digital technology are used within an instrumental rational discourse, providing citizens with better access to, and information on, public programmes. The whole idea of E-administration is often framed within such discourse (see Ekelin, 2007). This is also the case within the field of strategic political communication where the Internet is discussed with respect to its potential for fast circulation of large amounts of information that could de directed selectively to special groups and networks (Anduiza, 2009). SNSs (Social networking sites) such as Facebook and Twitter are discussed as an alternative to traditional media, as a way for politicians to circumvent its gatekeeping function and for direct communication with their constituencies (Zafiropoulos \& Vrana, 2009; Schweitzer, 2010). In this manner the ties between politicians and citizens are supposed to be reinforced and the information to the electorate better and more extensive (Anduiza, 2009; Zafiropoulos \& Vrana, 2009). The Internet is also supposed to attract undecided voters and mobilise slowcoaches (Anduiza, 2009; Montero, 2009).

Early on, instrumental rationality was criticised from many different perspectives (see March \& Simons 1958; Hindess, 1988). Since the fall of the Berlin Wall we have seen that neo-liberalism and self-interest are not easily converted into civic engagement (Youniss \& Bales \& Christmas-Best \& Diversi \& McLaughlin \& Silberreisen, 2002). In particular, parliamentary politics has come to be seen as inefficient for individuals when pursuing their private interests (Bellamy, 2008). In fact, most life-style political engagement in digital late modernity is problematic to understand in reference to instrumental rationality. If we consider the utilitarian argument of cost and benefits, it would make more sense not engage at all (the so called free-rider problem). Muhlberger (2006) refers to this as rational apathy. And here lies a problem. Instrumental rationality may explain civic disinterest towards political participation rationally, but it fails to provide a sufficient account of the new kinds of more self-reflective political engagement in digital late modernity.

In democratic theory there has been an increasing interest in Habermas' ideas of deliberation and the transformation of interest through political discourse (Mansbridge, 1990). In sharp contrast to strategic political spin, Habermas (1996) theorising about what procedures and qualities should persist communication within democratic fora, is applied more normatively as something to strive 
for and evaluate existing practices against. Habermas thus contrasts instrumental with communicative rationality. According to Habermas, the truth in our claims needs to be open to debate because they are inevitably based in our life-world of background assumptions, loyalties and skills (Leet, 1998). Therefore, to deal with our inherent subjectivity, Habermas (1996) points to critical interpersonal discussion as the mode of communication in a democracy. In order to understand each other and to become aware of our subjective assumptions, the only rational thing to do is to communicate with others. Communicative rationality occurs when communication is free from coercion, deception, strategising and manipulation (i.e the ideal speech situation). Communicative rationality suggests that people are motivated by a will to understand and learn from each other, thus differing from instrumental rationality where people are understood as being motivated by maximizing personal benefits at as a low cost as possible. Communicative rationality suggests that people are not only inclined to address their inherent subjectivity, they also want to strive for enlightenment through communication with others.

Notably, theoreticians of deliberative democracy have attempted to apply Habermas' normative philosophy and to evaluate democratic procedures according to ideas of an ideal public sphere where everybody is heard, can voice their concerns and consensus can be obtained when agreeing on the best arguments (Fishkin, 1991; Dryzek, 2000; Jodal, 2003). Deliberative democrats position themselves against the instrumental rational idea that decision-making is about aggregation and reconciliation of pre-established individual self-interest. Rational conversations (i.e. deliberations) are considered to have a democratising effect because participants are supposed to become more attuned to the common good of all rather than to negotiation between predetermined personal interests (Coleman \& Blumler, 2009; Svensson, 2008b). This deliberative democratic perspective has gained grounds within public administration and the institutions of representative democracy lately. The communicative view of citizens has become especially attractive when attempting to reorient citizens back to the fora of representative democracy (for a more thorough discussion see Svensson, 2008b).

The Internet was soon given attention because of its potential to engage citizens in deliberations within a larger framework of increasing civic participation in representative democracy (Coleman \& Blumler, 2009; Dahlgren, 2009; Kies, 2010). The emergence of the Internet coincided with lower participation in elections (Coleman \& Blumler, 2009; Dahlgren, 2009), and a deliberative turn within public administration (Svensson, 2008b). Within E-government, theorising contains elements of deliberative democracy (even though, as I pointed to before, in E-administration, the Internet is often framed as an instrument to better and more efficient services). Ekelin (2007) discusses Egovernment as also considering citizens active contribution. E-participation is described as processes of governance through deliberative discussions with the dual purpose of both empowering citizens at the same time as reinforcing the representative democratic model of democracy (ibid.). From this deliberative perspective E-participation is envisioned to benefit citizens, raise their interest for politics, increase direct and active citizen participation (ibid.). Eparticipation is thus dependent on comprehensive and sustained participation, and deliberative democrats often envision the Internet as a potential virtual agora full of ideas and rational discussion.

Deliberative democracy is not free from its critics and has been questioned from many different perspectives. According to the communicative understanding of rationality, ideas and demands must be inter-subjectively acceptable otherwise others will not go along with them. This has been considered unrealistic (Cohen, 1996; Elster, 1998). Deliberative normative ideas have been used for participatory democratic experiments as if the citizenry already possessed the rather demanding qualities necessary for successful deliberations (for such an example see Svensson, 2008b). Deliberative citizens need to be able to exercise self-restraint in refraining from the immediate instrumental purpose of their self-interests (Stokes, 2005). This attribute would need to be accompanied by the capacity for self-critique and an ability to listen to others and be open to revisions of earlier positions (ibid.). It is doubtful whether this very high standard of communicative action required is available among large numbers of citizens (McAfee, 2000; Stokes, 2005). This is 
certainly illustrated in commenting practices online, where anonymity and accessibility may lead to scornful comments, sometimes even hatred and defamation. Research has also indicated that political participation on the Internet most often is based in a high level of political participation offline (Calenda \& Mosca, 2007; Dahlgren \& Olsson, 2007; Vromen, 2007), and that users rather seem to seek confirmation of their already established viewpoints, than to expose oneself for new and diverging opinions (Sunstein, 2001; Anduiza, 2009).

\section{Motivating Deliberation?}

Discussing deliberative theory, scholars mostly attend to problems of the deliberation itself, its consequences, and often in a normative fashion (see Fishkin, 1991; 1995; Dryzek, 2000). But proponents of deliberative democracy seldom take into account why citizens are there in the first place. Before inhabitants deliberate, they have to be motivated to participate in deliberation. And in this lies a problem for deliberative democratic theory. In accounts of communicative rationality, the underlying assumption is that citizens have an intrinsic wish to talk to and understand each other. Thus, civic disinterest becomes difficult to explain in this tradition. If citizens were to be rationally communicative, there should not be a problem with civic apathy in the first place.

Studying motivation in this particular context brings back the relevance of instrumental rationality and self-interest for understanding civic political participation. Self-interest may indeed explain a lot of civic engagement (see Matsusaka, 1995). But as I have discussed earlier, while instrumental rationality easily could explain civic disinterest, it is more difficult understanding contemporary participation referring to instrumental rational self-interested agents. For example, why do users engage in discussion on online forums when it is highly unlikely that their engagement will lead to concrete policy making? On the other hand, communicative rationality fails to fully grasp the nature of the disinterested attitude towards representative democratic institutions in digital late modernity.

There have been attempts to combine instrumentally rational self-interest with communicative ideals of deliberative democracy. According to Wiklund (2005), even though people are initially motivated to participate by personal self-interest, these motives are supposed to be transformed in the process of deliberation in favor of the common good. In contrast to Wiklund I believe that instrumental rationality and deliberative democracy are incompatible in this context. My argument is that an appeal to self-interest, to be instrumental rationalists, will not create a communicative rational ideal speech situation, free from deception, strategising and manipulation. An appeal to self-interest will create egotistic expectations and behavior, not compatible with deliberative ideals of consensus and the supremacy of the better argument. As Mansbridge (1990) notes, it is indeed hard for a polity to simultaneously legitimate self-interest as well as to persuade its citizens to strive for the common good.

This is why I argue we need new tools in order to understand political participation in digital late modernity. Users on online forums rarely meet the deliberative theoreticians' strict standards of communicative rationality. But when citizens communicate with each other, online as well as offline, they produce meanings, identities, community, and public will in a way that theories yet have to capture (McAfee, 2000). The communicative transformations in digital late modernity challenge our perceptions; not least when it comes to political participation and citizenship practices. Here it is important not take on a determinist standpoint on either of technology and society when discussing citizenship (Ekelin, 2007, Frau-Meigs, 2007; Andrejevic, 2009; Roberts, 2009). Instead, more effort should be put into exploring mutual co-construction of citizenship and digital technology. According to Dobson (2003), aspects of citizenship change when social conditions change, hence technology, society and citizenship develop in a dialectical relationship. The citizen is constituted as a subject of a social practice and at the same time also constitutes him/ herself as a subject of a certain social (and technological) practice. Departing from theories of reflexivity and networked individualism in digital late modernity, my suggestion is to introduce identity and processes of reflexive identification in order to understand contemporary political participation and citizenship. An offline study by Walsh (2004) reinforces this argument. Observing informal political talk in groups of old men chatting at the corner store and women in handicraft groups, she argues that people neither gather to exchange political information, nor to deliberate on behalf of the common good (ibid.). When they talk, they are relating to each other with the aid of social identities. Walsh (2004) claims further that when people act together in movements or protests, they develop identities that help them understand who they are. These understandings 
will guide their future political engagements. What is actually happening when informal groups talk about politics is that they are engaging in identity development, and this I will argue is especially the case when political participation is taking place online.

\section{Expressive Rationality}

Brennan and Lomasky (1993) argue for expressive rather than individual preferences trying to understand why people vote. They claim that while self-interest is dominant in market behaviour, this is not applicable to voting behaviour. While agents are decisive in the market, agents are nondecisive at the ballot box (Brennan \& Lomasky, 1993). If you buy a book, you are indeed going to have the book, but if you vote Conservative you cannot be certain the Conservatives will win the elections. Therefore considerations that predominate at the market cannot be presumed to predominate at the ballot box. Where market behaviour reflects agents' self-interest, voting reflects agents' expressive preferences. In other words choosing A over B is different from expressing a preference for A over B (see also Engelen, 2006). Their argument can be applied to political participation, and especially so in digital environments. What is at stake here is identity and identification. This is how I am going to use their argument even though the authors themselves do not explicitly make this connection (considering they are part of the public choice tradition). Connecting identity and expressing preferences as a way to understand political participation, also fits very well into the late modern matrix of changing political practices. When citizens speak together, they produce meanings, identities, community and they express preferences. A focus on processes of identification thus concern expressing, maintaining and redefining discourses in order to make participation and deliberation meaningful and relevant for the citizen. This is neither communicative nor instrumental rationality. This would rather be expressive rationality. Citizens are motivated by a will to express, perform, maintain, create and recreate identities and their meanings (see also Engelen, 2006).

Let me give you examples of contemporary political practices. If I join a facebook group supporting the popular protests against Mubarak's regime in Egypt I show the world around me, including myself, that I am the kind of person who supports popular democratic movements and in the Arab world and that I am probably also against authoritarian regimes in general. If I sign an online petition against the deforestation in the Amazon, this shows that I am the kind of person who is environmentally concerned, and also that I am the kind of person who is similar to other people who are environmentally concerned. This does not only imply that I have certain political opinions, but may also very well include a certain lifestyle. A focus on identity and processes of identification concern expressing, maintaining and redefining discourses in order to make participation meaningful and relevant. Citizens thus are motivated by a will to express, perform, create and recreate identities and their meanings.

Giddens (1991) claims that self-identity concerns how we reflexively perceive ourselves out of our self-made biographies. Our personal identity needs a story, a sense of ontological coherence and continuity in our everyday life (ibid.). To keep this story/biography continuing is crucial for our personal identity (ibid.). Out of this argument it becomes rational to make our story explicit, to express our identities. Giddens (1991) refers to a reflexively organised endeavour. And to be successful in this, the individual needs to possess an ability to construct, deconstruct and reconstruct the own self-identity and biography (ibid.). Through active creation the individual maintain her constant self-biographical history (ibid.). And the creation of this biography becomes a source of meaning and engagement (ibid.). Out of this reasoning, maintaining and refining the stories of our selves becomes the motivating factor behind expressive rationality.

An expressive account of rationality may be used to explain civic disinterest as well as political participation in digital late modernity, if citizens are motivated by pre-established self-interests or not, and whether these will change during deliberations with others. Civic disinterest can be understood as lack of meaningful possibilities to perform, express and maintain identities, or simply a lack of relevant identities for making participation meaningful. Political participation is then motivated by meaningful and possible ways/ loci for expressing, maintaining and performing relevant identities.

I will give you an example from my current research project studying political participation of a network of active citizens in southern Stockholm. An issue that often engages the participation of inhabitants in this network concerns the preservation of green areas and playgrounds for the kids in 
the neighbourhood. This could be understood as a selfish act for your family. But it could also be understood as an act for the common good of all the children in the neighbourhood. But more importantly what was going on here in my opinion, is that the mothers and fathers are positioning themselves as concerned parents, and this identity made their participation in the public meeting relevant. They were showing to themselves, and to the rest of the participating inhabitants, that they were the kind of parents who cared for their children.

The major problem in the communicative as well as the instrumental account of civic participation, I believe, is their lack of recognising the prominence of identities and processes of identification for making participation relevant and meaningful. According to deliberative democracy, deliberation should shape the identity and interest of citizens (Cohen cited in Mansbridge \& Hartz-Karp \& Amengual \& Gastil, 2006). However a self-concept is necessary for taking part in deliberations in the first place (Portis, 1986). Also Walsh (2004) argues that a view of politics, stressing that people are reasoning together in order to promote common good that transcends their individual preferences, as well as a view supposing that peoples preferences, interests and identities are given in advance, misses the point. Neither vision recognizes that through casual interaction people/users create together the perspectives and identities with which they will understand public issues (ibid.).

From an instrumental perspective, expressive rationality would be considered problematic since expressive preferences may conceal actual personal preferences. In short, how to know what people really want in public deliberations? For example the preoccupation of the network of citizens in southern Stockholm to preserve green areas and playgrounds are framed in a discourse of the welfare of the kids in the neighbourhood. But this claim may in reality be about making the neighbourhood more attractive in order to increase the value of their properties. A municipality using a claim like that in order to construct a basketball field in concrete would perhaps not give these residents what they really want. On the other hand, concerns that deliberative democrats might hold would be present if egoistic self-interest is disguised as expressive preferences in public deliberations. As the example above shows, preserving green areas could be about personal finance and not about the children in the neighbourhood. According to deliberative theory it is people's opinions that are supposed to change, not the way they present their arguments. However, in my opinion, both perspectives fail to understand what is really going on here, that this claim is about expressing, developing and maintaining an identity as a concerned parent and active in the development of the neighbourhood (for a more detailed discussion on the parenthood identity see Svensson, 2007).

To sum up, from the perspective of expressive rationality we can understand participation both if citizens are motivated by pre-established self-interests or not, and whether these will change during deliberation with others. Instead of understanding private and public interest as diametrically opposed, these can go hand in hand, with one informing the other (Bellamy, 2008). Political participation for example, will function as an act of identity expression at the same time as the political community is sustained by citizen participation. Citizens strive to improve the structure and organisation of society through political participation and they pursue the goals and interests that give meaning to their lives on equal terms with others (Bellamy, 2008). These goals and interests may be self-centred as well as altruistic, hence both instrumental and communicative rationality may serve as forceful discourses around which to relate expressions of yourself, and meanings of your life, to. Expressive rationality then does not make instrumental and communicative rationality inadequate, but it is a different, more comprehensive and more adequate perspective for understanding political participation and citizenship. The practice of citizenship, and in the longterm, democracy, depends upon individuals regarding it as important to express their views on the just organization and equal structuring of society, among others. The Internet and digital environment provide us with such spaces.

\section{Expressive Rational Networked Individuals and the Other}

Discussing rationality, focusing on the expression and negotiation of the self, I have been questioned normatively for putting an emphasis on the individual instead of the collective. However, the kind of self-interest expressive rationality supposes is not necessarily in opposition to civicmindedness. The form of individualism occurring in digital networks, focusing on expressing preferences, identifying and maintaining the self, should not be confused with narcissism. 
Increasingly important characteristics emerging in late modern environments are responsiveness and connectedness (Frau-Meigs, 2007). Hence, negotiating and performing our selves as individuals does not per se imply a withdrawal from collective identities and community sensibilities. Here I find Castells (2001) idea of networked individualism enlightening to relate with the idea of expressive rationality. The idea of networked individualism underlines how individuals use the network to connect to others, to causes and to brands whose connotations are deemed rewarding for the shaping of the individual (since these connections are made visible on social communication platforms online, see Donath \& Boyd, 2004; Walther, Van Der Heide, Kim, Westerman \& Tong, 2008). In studies of the cell phone for example, informants claim that the phone enriched their social life, furthering opportunities for self-expression at the same time as managing and remaking relationships with friends and family (Pröitz, 2007).

If we address issues of the self, the idea of the other, is still important since we need others in order to maintain, develop, realise and express ourselves. For Simondon (referred to in Roberts, 2009) the production of the individual $I$, and the collective we, are inseparable (see also Lasch, 1991/1979). And we need others to develop healthy and corresponding self-images in order to remain mentally stable subjects living together in society. Early social psychology established the other, social groups and communities as necessary elements for concepts of the self and individualism (see Goffman, 1990/1959; Mead 1976/1934). Hence there is no conflict between the pursuit of individual identity and valuing larger collectives and social groups. In fact they are dependent on each other. What is different in digital late modernity is that communities and social groups also come, and increasingly so, in the shape of personalsed and self-made networks (Castells, 2001; Shirky, 2009).

Digitalisation goes hand in hand with processes of reflexivity and self-identity in late modernity, as I have highlighted with the concepts of digital late modernity and expressive rationality. Text messaging on the mobile phone is one example where various ways of cultivating and reinventing selves appear (Pröitz, 2007). This self-writing becomes an act of rationality for the writer him- or herself, in order to capture and manage what is said and heard in the process of the shaping of the self. It is, then, misleading to conceive of self-writing online, personal revelations and camphone self-portraits as narcissism or a culture of confession. Instead Pröitz (2007) suggests that we ought to conceive of these practices in relation to the power of memory, and being part of the storytelling of the self. As Giddens (1991) claims, our personal identity needs a biography, a sense of ontological coherence and continuity in our everyday life. To be successful in making our stories explicit (and hence expressing our identities), the individual needs to possess an ability to construct, deconstruct and reconstruct the own self-identity and biography (ibid.). Today, this identity maintenance work is increasingly done online.

As a critical scholar it is important not to put the question of power aside. Since online networks are based on reciprocity and trust, rather than on command and control (se Kjaer, 2004), mechanisms of power are more complex, finer and more difficult to grasp in a network full of interdependent nodes and connections. Power is both voluntary and coercive at the same time, not least since power mechanisms in networks are relational (Foucault, 1994). Critical studies in digital late modernity should thus not forget the question of what and who is governing the power relations in the network. I would guess that because of the increasing mobility of communication platforms and mobile access to the Internet, expressions and maintenance of network connections are taking place all the time, or at least have the possibility to take place all the time, disciplining the user to be constantly updated (in the double sense of the word - to be updated with the doings in the network as well as update the network with his/her doings, thoughts and feelings). The network form of communication thus disciplines us to build and maintain networks and possible surfaces of contact for information spreading. People are continually in touch, not least because technologies even stand in for us, leading to kind of connected presence in which we are constantly contactable. Hence Miller (2008) proclaims content is not king, but keeping in touch is, even underlining connectivity and responsiveness as dominant features in emerging sociabilities online (ibid.). Hence the expressive rationale in digital late modernity is based in other kinds of norms and values 
to which we have to position ourselves. The network also disciplines us to make our choices visible to others (the constant updating), argued by some, as I shall attend to next, to lead to a selfendorsed surveillance society.

As critical scholars it is important to be aware of that our expressions and biographies may be used for commercial and monitoring purposes. Commercial interests also largely operate beyond the possibility for transparency or user insight (Andrejevic, 2007). Issues of privacy and surveillance rarely get the attention of citizens when it concerns the commercial sphere, implying a different approach to the notions of personal privacy and integrity among younger citizens (Christensen, 2011). Private information is not understood as something protected but rather something to be managed and used towards personal and social ends (ibid.). On the Internet we are all visible all the time (connected presence), and we are also all watching all the time. We are objects of the constant gaze of others, and we are participating in this disciplining by free will in order to secure a place in the social arena. In fact it is not all clear today whether being watched on SNSs (social networking sites), or being used by others in their identity negotiation is exercising power or being subordinate to power. It all depends how skillfully the user navigates the new social arena and manages his or her databases of friends and information, governs his or hers visibility in the different context and front stages SNSs will be used. Christensen (2011) refers to a form of complicit surveillance in these contexts. In a similar argument Calvert (2000) claims that mediated exhibitionism (as different from mediated voyeurism) concerns well-directed and administrated revelations of personal information and selves hence redefining the meaning of exhibitionism towards a more expressive understanding of self-revelations online. Thus it seems that expressive rationality online puts forward the individual in a way that increasingly transcend, or go beyond, issues of privacy and integrity. When we negotiate and express our personality and ourselves on semi-public, personalised and, to some degree, self-managed networks online, the ideas of personal privacy and integrity becomes less relevant, or understood in a different manner. Here it seems that those with higher education and from a more resource-rich background use the Web for more capital-enhancing activities implying a second-level digital divide among Internet users (Hargittai \& Hinnant, 2008).

\section{Conclusion}

The focus on interactive media and cultural processes in late modernity has changed the focus of citizenship and participation, giving priority to processes of identification, self-realization and expression. Thus digital media consists of meaningware, bringing the expressive, textuality and meaning making to the fore (Liestöl, 2007). Rather than in narrow instrumental and communicative perspectives, a focus on identification underlines cultural aspects, which is both more interesting and more accurate when assessing political participation and citizenships in digital late modernity.

People now have access to several digital tools that let them share expressive content such as writing, images and video. Shirky (2009) claims that we are in the middle of the largest increase in expressive capability in the history of humanity. We should not forget that sharing ourselves online may be used, and is used for commercial and non-democratic purposes. The Internet is probably no cure against all forms of political disinterest, but it has provided new platforms for political participation. Sharing and publishing ourselves may result in new forms of citizenships. Citizenship has thus become more expressive and more networked. Political participation is coordinated in new, expanding and upcoming networks, providing new loci for expressing yourself as a citizen, as a member of society and your social and cultural belonging. 


\section{References}

Andrejevic, M. (2007). I Spy: Surveillance and Power in the Interactive Era. Lawrence: University Press of Kansas.

Andrejevic, M. (2009). Critical Media Studies 2.0: an interactive upgrade. Interactions. Studies in Communication and Culture, 1(1)

Anduiza, E. (2009). The Internet, election campaigns and citizens: state of affairs. Quaderns del CAC. December 2009 ,512.

Arsenjuk, L. (2005). Introduktion till Jacques Rancière. Fronesis, 19 (20)

Bauman, Z. (2001). The Individualized Society. Cambridge: Polity Press.

Beck, U. (1995). Att uppfinna det politiska: Bidrag till en teori om reflexiv modernisering. Göteborg: Daidalos.

Beck, Ulrich (1998). Risksamhället; På väg mot en andra modernitet. Göteborg: Daidalos.

Bellamy, R. (2008). Citizenship: A Very Short Introduction, New York, Oxford University Press. 2008.

Benkler, Y. (2006). The Wealth of Networks: How Social Production Transforms Markets and Freedom. New Haven: Yale University Press.

Bentivegna, S. (2006). Rethinking Politics in the World of ICTs. In European Journal of Communication, 21(3), 295-309.

Boggs, C. (2000). The End of Politics. Corporate Power and the Decline of the Public Sphere. New York: Guilford Press.

Bosniak, L. (2006). The Citizen and the Alien: Dilemmas of Contemporary Membership. Princeton: Princeton University Press.

Brennan, G. \& Lomasky, L. E. (1993). Democracy and Decision: The Pure Theory of Electoral Preference. Cambridge: Cambridge University Press.

Calenda, D. \& Mosca, L. (2007). Youth online. Researching the political use of the Internet in the Italian context. In B. D. Loader (Ed.), Young Citizens in the Digital Age: Political Engagement, Young People and New Media. London: Routledge.

Calvert, C. (2000). Voyeur Nation: Media, Privacy and Peering in Modern Culture. Boulder, Colorado: Westview Press.

Carter, A. \& Stokes G. (1998). Introduction. Liberal Democracy and its Critics. In A. Carter \& G. Stokes (Eds.), Liberal Democracy and its Critics. Cambridge: Polity Press.

Castells, M. (2001). The Internet Galaxy: Reflections on the Internet, Business and Society. Oxford: Oxford University Press.

Christensen, M. (2011). Online Social Media, Communicative Practice and Complicit Surveillance in Transnational Contexts. In M. Christensen, A. Jansson, \& C. Christensen (Eds.), Online Territories: Globalization, Mediated Practice and Social Space. NY: Peter Lang Publishing.

Cohen, J. (1996). Procedure and Substance in Deliberative Democracy. In S. Benhabib (Ed.), Democracy and Difference of the Political. Princeton: Princeton University Press.

Coleman, S. \& Blumler J. G. (2009). The Internet and Democratic Citizenship: Theory Practice and Policy. New York, Cambridge University Press.

Dahlberg, L. (2005). The Internet as Public Sphere or Cultural Industry? From Pessimism to Hope and Back. International Journal of Media and Cultural Politics, (1)1, 93 -96.

Dahlgren, P. (2001). The Public Sphere and the Net: Structure, Space and Communication. In L. Bennet \& R. Entman (Eds.), Mediated Politics: Communication in the Future of Democracy. Cambridge: Cambridge University press.

Dahlgren, P. (2006). Civic Identity and Net activism. The Frame of Radical Democracy. In L. Dahlberg \& E. Siapera (Eds.), Radical Democracy and the Internet. London: Palgrave MacMillan.

Dahlgren, P. (2009). Media and Political Engagement. Citizens, Communication, and Democracy. New York: Cambridge University Press.

Dahlgren, P. \& Olsson, T. (2007). Young activists, political horizons and the Interenet: adapting the net to one's purposes. In B. D. Loader (Ed.), Young Citizens in the Digital Age: Political Engagement, Young People and New Media. London: Routledge.

Delanty, G. (2002). Communitarianism and Citizenship. In E. Isin \& B. Turner (Eds.), Handbook of Citizenship Studies. London: Sage.

Dobson, A. (2003). Citizenship and the Environment. New York: Oxford University Press.

Donath, J., \& Boyd, D. (2004). Public Displays of Connection. BT Technology Journal, (22)4.

Downs, A. (1957). An Economic Theory of Democracy. New York: Harper \& Row.

Dryzek, J. (2000). Deliberative Democracy and Beyond: Liberals, Critics, Contestations. Oxford: Oxford University Press. 2000.

Ekelin, A. (2007). The Work to Make eParticipation Work. Blekinge Institute of Technology Doctoral Dissertation Series no 2007: 11, Karlskrona, Blekinge Institute of Technology.

Elster, J. (1998). Deliberative Democracy. Cambridge: Cambridge University Press. 
Engelen, B. (2006). Solving the paradox. The Expressive Rationality of the Decision to Vote. Rationality and Society. 18 (3).

Foucault, M. (1994). Power. Essential Works of Foucault 1954-1984. Volume 3. J. D. Faubion (Ed.). London: Penguin Books.

Fishkin, J. S. (1991). Democracy and Deliberation: New Directions for Democratic Reform. New Haven: Yale University Press.

Frau-Meigs, D. (2007). Convergence, Internet Governance and Cultural Diversity. In T. Storsul \& D. Stuedahl (Eds.), Ambivalence Towards Convergence: Digitalization and Media Change. Göteborg: Nordicom.

Fukuyama, F. (1992). The End of History and the Last Man. New York: Maxwell Macmillan International.

Giddens, A. (1991). Modernity and Self-Identity: Self and Society in the Late Modern Age. Cambridge: Polity Press.

Goffman, E. (1990). The Presentation of Self in Everyday Life. Harmondsworth: Penguin books. First published 1959.

Habermas, J. (1984). The Theory of Communicative Action I: Reason and the Rationalization of Society. Boston: Beacon Press.

Habermas, J. (1996). Kommunikativt handlande: Texter om språk rationalitet och samhälle. $2^{\text {nd }}$ Edition, Göteborg: Daidalos.

Hargittai, E. \& Hinnant, A. (2008). Digital Inequality: Differences in Young Adults' Use of the Internet. Communication Research, 35 (5).

Hindess, B. (1988). Choice, Rationality and Social Theory. London: Unwin Hyman.

Hindman, M. (2009). The Myth of Digital Democracy. Princeton: Princeton University Press.

Horkheimer, M. (1947). Eclipse of Reason. New York: Oxford University Press.

Jodal, O. (2003). Fem frågetecken för den deliberativa teorin. In M. Gilljam \& J. Hermansson (Eds.), Demokratins mekanismer. Malmö: Liber.

Kies, R. (2010). Promises and Limits of Web-deliberations. New York: Palgrave MacMillan.

Kjaer, A. M. (2004). Governance. Cambridge: Polity Press.

Kivisto, P. \& Faist, T (2007). Citizenship. Discourse, Theory and Transnational Prospects, Key Themes in Sociology, Malden: Blackwell Publishing.

Lasch, C. (1991). The Culture of Narcissism. American Life in an Age of Diminishing Expectations. New York: W. W. Norton \& Company. First published 1979.

Leet, M. (1998). Jurgen Habermas and Deliberative Democracy. In A. Carter \& G. Stokes (Eds.), Liberal Democracy and its Critics. Cambridge: Polity Press.

Liestöl, G. (2007). The Dynamics of Convergence and Divergence. In T. Storsul \& D. Stuedahl (Eds.), Ambivalence Towards Convergence: Digitalization and Media Change. Göteborg: Nordicom.

Loader, B. D. (2007). Young Citizens in the Digital Age: Political Engagement, Young People and New Media. New York: Routledge.

Lüders, M. (2007). Convergent Forms of Communication? In T. Storsul \& D. Stuedahl (Eds.), Ambivalence Towards Convergence: Digitalization and Media Change. Göteborg: Nordicom.

Mansbridgde, J. (1990). Beyond Self-interest. Chicago: University of Chicago Press.

Mansbridge, J. \& Hartz-Karp, J. \& Amengual, M. \& Gastil, J. (2006). Norms of Deliberation: An Inductive Study. Journal of Public Deliberation, 2 (1).

March J. G. \& Simon, H. A. (1958). Organizations. New York: Wiley.

Mastsusaka, J. G. (1995). The Economic Approach to Democracy. In M. Tomasi \& K. lerulli (Eds.), The New Economic of Human Behaviour. Cambridge: Cambridge University Press.

McAfee, N. (2000). Habermas, Kristeva and Citizenship. Ithaca: Cornell University Press.

Mead, G. H. (1976). Medvetandet, jaget och samhället: från socialbehavioristisk ståndpunkt. Lund: Argos. First published 1934.

Medierådet (2010). Unga \& Medier 2010. Fakta om barns och ungas användning och upplevelser av medier. Stockholm: Kulturdepartementet. http://www.medieradet.se/upload/Rapporter pdf/Ungar\%20och\%20medier\%202010.pdf, retrieved 8/12 2010

Miller, V. (2008). New Media, Networking and Phatic Culture. In Convergence The International Journal of Research into New Media Technologies, (14) 4, 387-400.

Montero, M. D. (2009). Political e-mobilisation and participation in the election campaigns of Ségolène Royal (2007) and Barack Obama (2008). Quaderns del CAC, December 2009, 27-34.

Montin, S. (2002). Moderna kommuner. Malmö : Liber.

Mueller, D. (1989). Democracy: The public Choice Approach. In G. Brennan \& L. Lomasky (Eds.), Politics and Process: New Essays in Democratic Thought. Cambridge: Cambridge University Press.

Muhlberger, P. (2006). Lessons from the Virtual Agora Project: The Effects of Agency, Identity, Information, and Deliberation on Political Knowledge. Journal of Public Deliberation, (2) 1. 
Nord, L. (2008), Medier utan politik. En studie av de svenska riksdagspartiernas syn på press, radio och TV. Stockholm : Santérus Förlag.

Olsson, T. \& Dahlgren, P. (2010). Young People ICTs and Democracy. Theories, Policies, Identities and Websites. Göteborg: Nordicom.

Oostveen A. (2009). Citizens and Activists: Analysing the Reasons, Impact and Benefits of Civic Emails Directed at a Grassroot Campaign. Paper presented at the Mediated Citizenship conference, University of Leeds, 17-18 September 2009.

Petersson, O., \& Westholm, A., \& Blomberg, G. (1989). Medborgarnas Makt. Stockholm: Carlssons.

Pocock, J. G. A. (1995). The Ideal of Citizenship Since Classical Times. In R. Beiner (Ed.), Theorizing Citizenship. Albany: State University of New York Press.

Pröitz, L. (2007). Mobile Media and Genres of the Self. In T. Storsul \& D. Stuedahl (Eds.), Ambivalence Towards Convergence: Digitalization and Media Change. Göteborg: Nordicom.

Roberts, B. (2009). Beyond the "Networked Public Sphere: Politics, Participation and Technicsin Web 2.0. In FibreCulture, 14 (2009). http://journal.fibreculture.org/issue14/issue14 roberts.html (downloaded 2009-10-13)

Schweitzer, E. J. (2010). Mediatized Politics on the Internet. Evidience From a Multi-Level Analysis of German Online Campaigns in State, National, and European Parliamentary Elections. Paper presented at the $3^{\text {rd }}$ European Communication Conference of the European Communication Research and Education association (ECREA), Hamburg, Germany.

Shirky, C. (2009). Here Comes Everybody: How Change Happen when People Come Together. London: Penguin Books Ltd.

Smith, R. M. (2002). Modern Citizenship. in E. Isin \& B. Turner (Eds.), Handbook of Citizenship Studies. London: Sage.

Stokes, G. (2005). Critical Theories of Deliberative Democracy and the Problem of Citizenship, Paper presented at the Institute for Citizenship and Globalisation seminar, Deakin University, Burwood, Australia, 4 October 2005.

Sunstein, C. (2001). Republic.com. Princeton: Princeton University Press.

Svensson, J. (2007). The Actively Engaged Parent as the Ideal Citizen. International Journal of Media \& Cultural Politics, (3) 2, 194-197.

Svensson, J. (2008a). Expressive Rationality: A Different Approach for Understanding Participation in Municipal Deliberative Practices. In Communication, Culture and Critique, (1) 2, 203-211.

Svensson, J. (2008b). Kommunikation, medborgarskap och deltagardemokrati. En studie av medborgarutskotten $i$ Helsingborg. Lund Studies in Media and Communication 10, Lund: Sociologiska institutionen.

Terranova, T. (2004). Network Culture: Politics for the Information Age. London: Pluto Press.

Turner, B. S. (1994). Postmodern Culture/Modern Citizens. In B. van Steenberger (Ed.), The Condition of Citizenship. London: Sage.

Walsh, K (2004). Talking about Politics: Informal Groups and Social Identity in American Life. Chicago: The University of Chicago Press.

Walther, J. B \& Van Der Heide, B. \& Kim, S. \& Westerman, D. \& Tong, S. T. (2008). The Role of Friends' Appearance and Behavior on Evaluations of Individuals on Facebook: Are We Known by the Company We Keep? Human Condition Research, (2008)34.

Wiklund, H. (2005). A Habermasian Analysis of the Deliberative Democratic Potential of ICT-Enabled Services in Swedish Municipalities. In New Media \& Society, 7 (2).

Vromen, A. (2007). Australian young people's participatory practices and Internet use. in B. D. Loader (Ed.), Young Citizens in the Digital Age: Political Engagement, Young People and New Media. London: Routledge.

Youniss, J. \& Bales, S. \& Christmas-Best, V. \& Diversi, M. \& McLaughlin, M. \& Silberreisen, R. (2002). Youth Civic Engagement in the Twenty-First Century. In Journal of Research on Adolescence, (12), 121-148.

Zafiropoulos, K. \& Vrana, V. (2009). The impact of political events on blog conversational patterns: two cases from Greece. Quaderns del CAC, December 2009, 77-85.

\section{About the Author}

\section{Jakob Svensson}

Dr. Jakob Svensson is a young researcher with a PhD in Media and Communication Studies (12 June 2008). His particular interest is in Civic Communication, political participation and the construction of citizenship through online communicative practices. Jakob is currently holding a position of assistant professorship in Media and Communication Studies at Karlstad University and is the Director of the research network HumanIT, Human Values of Information and Communication Technology (www.kau.se/en/humanit). 